\title{
UPAYA PENGEMBANGAN MAKANAN LOKAL "BE KEREN" BERBASIS WISATA KULINER DI KELURAHAN KAWAN, BANGLI, BALI
}

\author{
I Gusti Ayu Ari Agustini \\ Email: ari.agustini@pib.ac.id \\ POLITEKNIK INTERNASIONAL BALI
}

\begin{abstract}
The diversity of Balinese culinary possesses great potential as a supporting element in developing culinary tourism in Bali. Culinary-based tourism is an alternative for tourists besides other tourism choices, such as cultural tourism, nature tourism, and marine tourism which have been known by all visitors coming to Bali. One of the Balinese culinary specialties is Ayam Be Keren which is originated from Bangli Regency.

The purpose of this research is to find out the attempts to develop the Balinese culinary specialty, Ayam Be Keren and also to find out the obstacles faced in the development process. The method of data analysis used is descriptive qualitative analysis using several informants that selected purposively. Data collection techniques were carried out by doing observation, in-depth interviews and documentation by using developed theories, such as the theory of product development and gastronomic theory.

The results showed that the traditional dish from Bangli, Ayam Be Keren is needed to develop to be a tourist attraction. The attempts that can be done are preparing well trained human resources to fulfill the production capacity existing nowadays. The sufficient human resources will be able to increase production leading to the development of facilities which then will be followed by the development of more professional management.
\end{abstract}

Keywords: Development Potency, Local Food Be Keren, Culinary Tourism

\begin{abstract}
Abstrak
Keanekaragaman kuliner di Pulau Bali membuat kuliner khas Bali menyimpan potensi yang besar untuk dikembangkan sebagai jasa penunjang dalam pengembangan potensi wisata kuliner. Wisata berbasis kuliner menjadi salah satu alternatif disamping pilihan jenis wisata lainnya seperti wisata budaya, wisata alam dan wisata bahari yang sudah terlebih dahulu dikenal oleh wisatawan yang datang ke Bali. Salah satu makanan khas Bali tersebut adalah Ayam Be Keren yang berasal dari Kabupaten Bangli.
\end{abstract}


Tujuan penelitian ini untuk mengetahui adanya upaya pengembangan kuliner khas Bali Ayam Be Keren, serta untuk mengetahui kendala yang dihadapi dalam proses pengembangannya. Metode analisis data yang digunakan adalah analisis deskriptif kualitatif menggunakan beberapa informan yang dipilih secara purposive. Teknik pengumpulan data dilakukan dengan metode observasi, wawancara mendalam dan studi dokumentasi dengan menggunakan teori yang dikembangkan berupa teori pengembangan produk dan teori gastronomi.

Hasil penelitian menunjukkan bahwa makanan tradisional khas Bangli Ayam $B e$ Keren perlu dikembangkan agar dapat dijadikan sebagai daya tarik wisata. Upaya yang dapat dilakukan untuk mengembangkannya yaitu dengan menyiapkan tenaga kerja yang terlatih dan sesuai dengan kebutuhan sehingga mampu memenuhi kapasitas produksi yang dimiliki saat ini. Dengan sumber daya manusia yang dimiliki juga akan mampu meningkatkan produksi yang mengarah pada pengembangan sarana dan prasarana, yang kemudian diikuti dengan pengelolaan manajemen kerja yang lebih profesional.

Kata Kunci: Potensi Pengembangan, Masakan Lokal Be Keren, Wisata Kuliner

\section{Pendahuluan}

Kabupaten Bangli memiliki sebuah keunikan makanan khas daerah. Ayam Be Keren (kedua huruf e pada 'Keren' dibaca seperti membaca huruf e pada kata dengan) adalah salah satu kuliner khas Bangli yang sudah cukup dikenal banyak wisatawan lokal maupun asing. Be Keren adalah makanan serupa ayam betutu yang dimasak dengan cara yang khas yaitu dibakar dengan menggunakan sekam dan sabut kelapa selama kurang lebih 12 jam. Ayam yang digunakan untuk $B e$ Keren adalah ayam merah dan dibumbui 'Basa Gede' atau bumbu lengkap. Aroma bumbu tersimpan rapi karena dibungkus dengan pelepah pinang, sehingga waktu dibuka aromanya dapat membuat perut lapar. Untuk rasa, hampir mirip dengan ayam betutu pada umumnya, yang membedakan yaitu aroma pelepah pinang yang memberi tambahan sensasi berbeda dan rasanya yang lebih gurih. 
Ayam $B e$ Keren dahulu hanya dimasak khusus saat hari raya ataupun saat ada upacara jamuan khusus untuk setingkat bangsawan dan para raja. Masakan Ayam Keren ini merupakan tata cara masak tradisional yang diwariskan secara turun temurun di dapur-dapur penduduk di Bangli sejak jaman dulu. Saat ini hanya tinggal sedikit orang yang bisa memasak Ayam $B e$ Keren ini dengan cara yang baik dan benar. Asal mula dinamakan Keren, yaitu dikarenakan proses memasaknya yang memakan waktu cukup lama yaitu 12 jam, yang diibaratkan seperti induk ayam yang sedang mengerami ayamnya, eram berangsur menjadi kerem dan akhirnya disebut dengan Keren, (Wawancara Sugantini, 20 Januari 2019). Namun demikian masih sangat beruntung ada Ibu Agung Sugantini yang meneruskan tradisi membuat Ayam Keren ini, melestarikannya dan mengembangkannya sebagai bisnis, sehingga masyarakat yang sudah tidak bisa lagi cara memasak Ayam Be Keren (atau tidak punya waktu untuk membuatnya) kini tetap bisa menikmati Ayam Be Keren.

Wisata kuliner Ayam $B e$ Keren menjadi suatu alternatif dalam mendukung potensi wisata alam, wisata budaya, wisata sejarah dan wisata bahari. Wisata kuliner ini menjadi bagian dari jenis wisata yang ada, karena tidaklah lengkap kalau wisatawan yang datang tidak mencoba kuliner khas Bangli ini. Meskipun wisata kuliner sering dianggap sebagai produk wisata pelengkap, tetapi wisata kuliner potensial untuk dikembangkan karena wisatawan yang datang biasanya tertarik untuk mencoba makanan khas daerah yang dikunjungi. Pemerintah Kabupaten Bangli dan pelaku usaha perlu mencermati peluang ini untuk memperkenalkan kuliner khas Bangli kepada wisatawan yang berkunjung, baik itu wisatawan asing maupun lokal. Hal ini merupakan tantangan bagi pemerintah dan pelaku usaha dalam melihat peluang dan memanfaatkan kuliner khas Bangli sebagai upaya dalam mendukung wisata kuliner di Propinsi Bali. 


\section{Konsep Dan Teori}

Konsep dan teori yang dipilih untuk menjelaskan penelitian ini terangkum sebagai berikut.

\subsection{Makanan Tradisional}

Emayanti (2003:2) dalam Ensiklopedi Makanan Tradisional di Pulau Jawa dan Pulau Madura memberikan pengertian bahwa makanan tradisional memiliki nilai budaya, tradisi, serta kepercayaan yang bersumber pada budaya lokal (local indigenous) sangat berpengaruh terhadap pola makanan suku-suku di Indonesia, termasuk diantaranya pemilihan bahan mentah, corak dan tradisi makan, kebiasaan makan dan cara penyajian. Makanan tradisional suatu daerah bisa menjadi cermin peradaban dan budaya suatu daerah, akan tepat disuguhkan serta dinikmati pula oleh masyarakat setempat.

Berdasarkan pengertian tersebut maka dapat disimpulkan bahwa makanan tradisional ialah makanan asli atau khas daerah tertentu di Indonesia dimana dalam proses pengolahannya sangat dikuasai oleh masyarakat di daerah tersebut, serta cita rasanya sangat sesuai dengan masyarakat setempat. Karena proses pengolahan serta cita rasanya sangat identik dengan masyarakat tertentu, bahkan makanan ini bisa dijadikan tolok ukur ciri khas suatu daerah tertentu.

\subsection{Potensi Dan Daya Tarik Wisata}

Pendit (1999: 21) menyebutkan bahwa potensi wisata adalah berbagai sumber daya yang terdapat di sebuah daerah tertentu yang bisa dikembangkan menjadi atraksi wisata. Dengan kata lain, potensi wisata berbagai sumber daya yang dimiliki oleh suatu tempat dan dapat dikembangkan menjadi suatu atraksi wisata (tourism attraction) yang dimanfaatkan untuk kepentingan ekonomi dengan tetap memperhatikan aspek-aspek lainnya. 
Menurut Cooper (1998: 81) mengemukakan bahwa terdapat empat komponen yang harus dimiliki oleh sebuah destinasi wisata, yaitu:

a. Atraksi (Attraction), seperti alam yang menarik, kebudayaan daerah yang menawan dan seni pertunjukan.

b. Aksesibilitas (Accessibilities), seperti transportasi lokal, terminal angkutan.

c. Amenities/Fasilitas (Amenities), seperti tersedianya akomodasi, rumah makan dan agen perjalanan.

d. Organisasi Kepariwisataan (Ancillary Services) yaitu pelayanan wisata seperti destination marketing management organization, conventional and visitor bureau.

Undang-undang No. 10 Tahun 2009 menguraikan objek dan daya tarik wisata sebagai segala sesuatu yang menjadi sasaran wisata. Objek dan daya tarik wisata yang dimaksud adalah:

a. Daya tarik wisata adalah segala sesuatu yang memiliki keunikan, keindahan, dan nilai yang berupa keanekaragaman kekayaan alam, budaya, dan hasil buatan manusia yang menjadi sasaran atau tujuan kunjungan wisatawan.

b. Daerah tujuan pariwisata yang selanjutnya disebut Destinasi Pariwisata adalah kawasan geografis yang berada dalam satu atau lebih wilayah administratif yang didalamnya terdapat daya tarik wisata, fasilitas umum, fasilitas pariwisata, asesibilitas, serta masyarakat yang saling terkait dan melengkapi terwujudnya kepariwisataan.

Damanik dan Weber (2006) menambahkan bahwa "daya tarik wisata yang baik sangat terkait dengan empat hal, yaitu memiliki keunikan, orijinalitas, otentisitas, dan keragaman". Keunikan diartikan sebagai kombinasi kelengkapan dan kekhasan yang melekat pada suatu daya tarik wisata. Orijinalitas mencerminan keaslian atau kemurnian, yakni seberapa jauh suatu produk tidak terkontaminasi atau tidak mengadopsi nilai yang 
berbeda dengan nilai aslinya. Otentisitas mengacu pada keaslian. Bedanya dengan orijinalitas, otentisitas lebih sering dikaitkan dengan tingkat keantikan atau eksotisme budaya sebagai daya tarik wisata. Ontetisitas merupakan kategori nilai yang memadukan sifat alamiah, eksotis, dan bersahaja.

\subsection{Teori Pengembangan Produk Dan Gastronomi}

Pengembangan produk pada dasarnya adalah usaha yang dilakukan secara sadar dan berencana untuk memenuhi produk yang sedang berjalan atau menambah jenis yang sudah ada. Pengembangan produk menurut Kotler dan Amstrong (2004: 399) adalah pengembangan produk original, perbaikan produk, modifikasi produk dan merek baru yang dikembangkan. Menurut Assauri (2001: 199) pengembangan produk merupakan suatu kegiatan atau aktivitas yang dilakukan dalam menghadapi kemungkinan perubahan suatu produk kearah yang lebih baik, sehingga dapat memberikan daya guna dan daya pemuas yang lebih besar. Tujuan pengembangan produk menurut Bucharin (2000: 101) yaitu untuk memenuhi keinginan konsumen yang belum puas, untuk menambah omzet penjualan, untuk memenangkan persaingan, untuk mendayagunakan sumber-sumber produksi, untuk meningkatkan keuntungan dengan pemakaian bahan yang sama, untuk mendayagunakan sisa-sisa bahan, untuk mencegah kebosanan konsumen, dan untuk menyederhanakan produk pembungkus.

Gastronomi atau tata boga adalah seni atau ilmu akan makanan yang baik (good eating). Penjelasan yang lebih singkat menyebutkan gastronomi sebagai segala sesuatu yang berhubungan dengan kenikmatan dari makan dan minuman. Istilah gastronomi pertama kali muncul pada judul sebuah puisi di Perancis pada tahun 1801 (Berchoux, 1804 dalam Scarpato, 2002) yang berhubungan dengan kenikmatan dalam menikmati 
makanan dan minuman. Teori pengembangan produk dan teori gastronomi ini digunakan untk menganalisis rumusan masalah yang berhubungan dengan kendala dalam pengembangan sekaligus potensi pengembangannya sebagai daya tarik wisata di Kabupaten Bangli.

\section{Metode Penelitian}

Penelitian ini menggunakan metode kualitatif. Spradley dalam Sugiyono (2010) menyebutkan bahwa gejala untuk menentukan variabelvariabel yang akan diteliti bersifat holistik sehingga penelitian tidak akan ditetapkan berdasarkan variabel penelitian saja, melainkan keseluruhan situasi sosial yang meliputi aspek tempat (place), pelaku (actor), dan aktivitas (activity) yang berinteraksi secara sinergis. Menurut Nazir (2003: 71) penelitian deskriptif analisis kerja dan aktivitas ditujukan untuk menyelidiki secara terperinci aktivitas dan pekerjaan manusia, seperti gerak-gerik mereka dalam melakukan tugas, penggunaan waktu secara efektif dan efisien, dan sebagainya, dan hasil penelitian tersebut dapat memberikan rekomendasi-rekomendasi untuk keperluan masa yang akan datang.

Melalui pengamatan atau observasi, wawancara dan studi dokumentasi, baik terhadap pedagang maupun masyarakat lokal mengenai pengembangan makanan tradisional Bali, selanjutnya hasil kumpulan pendapat informan tersebut yang berupa data akan dipaparkan dengan menggunakan metodek desriptif kualitatif.

\section{Upaya Pengembangan Makanan Lokal $B e$ Keren}

\subsection{Pengolahan Ayam Be Keren}

Proses pengolahan ayam diawali dengan pembersihan kemudian melumuri daging ayam dengan garam secara merata dan dipijat-pijat untuk melenturkan dan meresapkan ke seluruh bagian. Setelah itu ayam 
diletakkan di atas pembungkus, satu lembar daun Upih (pelepah pinang) lalu diberi bumbu 'Basa Gede' yang telah diulek halus secara merata, kemudian diberi lebih banyak dibagian perut ayam. Basa Gede adalah campuran adonan yang diulek dengan bahan-bahan antara lain: bawang merah, bawang putih, cabe, garam, lengkuas, kunyit, jahe, kencur, ketumbar, merica, cabe kecil, terasi, dan kemudian diberi tambahan beberapa lembar daun salam. Berikutnya Ayam yang telah dibumbui ini dibungkus dengan rapi dan diikat satu bagian, lalu diberi tambahan minyak kelapa dan air melalui bagian lainnya, kemudian diikat dengan rapat menggunakan tali dari bahan bambu. Tujuan membungkus rapat ayam beserta bumbunya yaitu membantu memastikan bahwa aroma dan rasa bumbu tidak menghilang saat proses memasak, namun tetap tertinggal dan meresap ke dalam daging ayam.

Setelah dibumbui dan dibungkus dengan Upih, ayam dimasak dengan cara membakarnya di atas tungku sekam, lalu dieram di dalam paso tanah liat lalu dikubur lagi dengan sekam dan dibakar dengan menggunakan sabut kelapa. Itulah sebabnya mengapa masakan ini disebut dengan nama $B e$ Keren, karena keren maksudanya adalah kerem, mengeram. Kegunaan sekam dan sabut kelapa ini memperkaya cita rasa Ayam $B e$ Keren. Ayam dimasak selama 12 jam hingga bisa dikatakan matang dengan baik, kondisi Upih bisa dikatakan tetap utuh, hanya terbakar dibeberapa area saja, walaupun sekam telah terbakar habis menjadi abu.
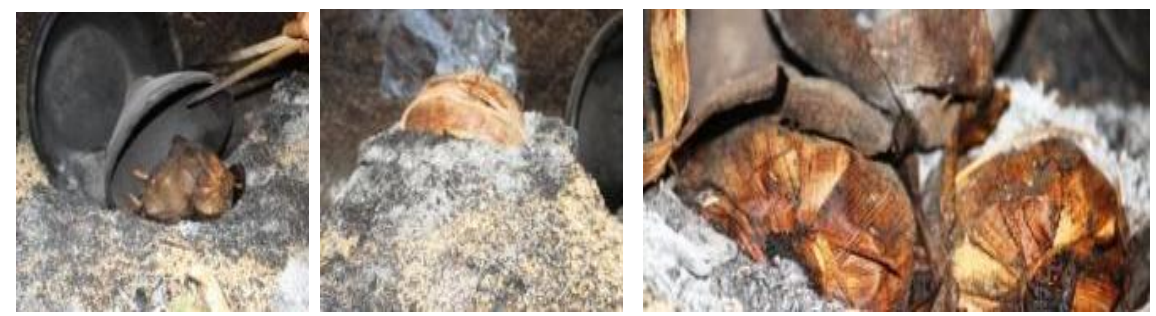

Gambar 1. Proses Pembakaran Ayam Be Keren

Sumber: Hasil Observasi Peneliti, 2019 

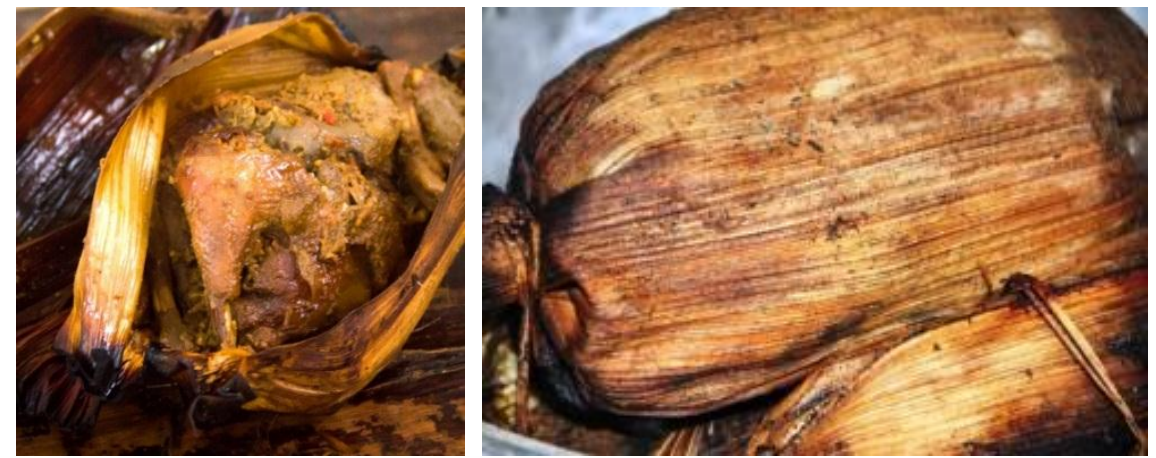

Gambar 2. Tampilan Ayam Be Keren Dalam Kemasan Upih Sumber: Hasil Observasi Peneliti, 2019

Dapur untuk memasak $B e$ Keren, adalah sebuah ruangan khusus, dengan luas kurang lebih 2,5 x 3m dan tingginya dibuat kurang lebih $7 \mathrm{~m}$. Seluruh dinding berbahan dasar bata merah, dimana pada bagian atas dibuat celah udara disekeliling bawah atap dengan celah kurang lebih $1 \mathrm{~m}$. Dapur tersebut merupakan warisan turun-temurun keluarga Puri Agung Bangli, yang memang digunakan khusus untuk proses memasak $B e$ Keren. Sampai dengan saat ini belum pernah dilakukan perbaikan/ perubahan yang besar terhadap struktur bangunan dapur tersebut. Jadi dapat dikatakan bahwa dapur tersebut masih merupakan bangunan orijinil.
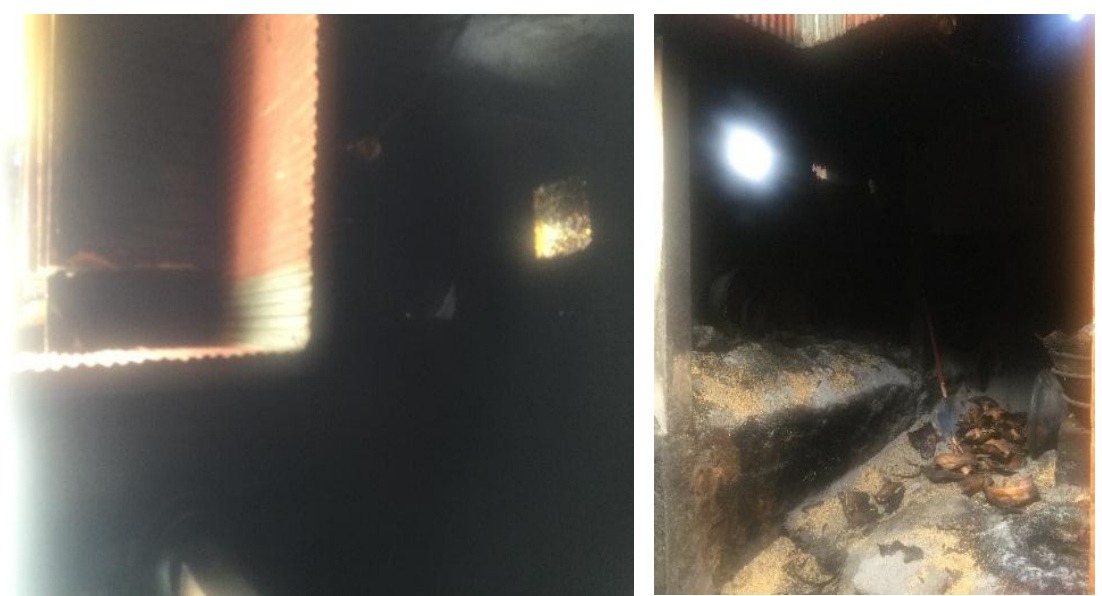

Gambar 3. Tampilan Dapur Tempat Memasak Be Keren Sumber: Hasil Observasi Peneliti, 2019 


\subsection{Kendala Pengembangan Ayam Be Keren}

Adapun yang menjadi kendala di dalam pengembangannya, antara lain:

a. Sarana dan Prasarana

Bahwa semenjak perkembangan dunia teknologi beberapa tahun terakhir, dan setelah adanya liputan langsung dari berbagai TV Nasional dan beberapa Stasiun TV Luar, Ayam Be Keren yang dikelola mengalami peningkatan produksi yang cukup signifikan. Berbagai liputan di media sosial sangat membantu perkembangan Ayam Be Keren. Hal ini tidak terlepas dari peran serta konsumen yang turut serta menginformasikan keberadaan $B e$ Keren melalui postingan yang dilakukan oleh masing-masing akun media sosial pribadi. Perkembangan ini menjadi kendala tersendiri untuk Ibu Agung selaku penjual, dimana sarana dan prasarana yang dimiliki bisa dikatakan terbatas, dimana satu area dapur yang dimiliki hanya dapat digunakan untuk mengolah kurang lebih 100 bungkus Ayam Be Keren dalam 1 hari penuh (24 jam). Begitu juga kendala penunjang lainnya, seperti Upih (Daun Pelepah Pinang), bisa dikatakan tidak begitu mudah didapat. Saat ini Ibu Agung sudah mendatangkan Upih dari luar Kabuaten Bangli, yaitu dari Kabupaten Singaraja dan Karangasem, dikarenakan di Bangli sendiri kecukupan daun Upih sudah tidak maksimal dapat memenuhi kebutuhan yang ada.

b. Kapasitas Produksi

Adanya peningkatan pesanan tersebut berdampak pada kapasitas produksi $B e$ Keren, sebelumnya hanya dilakukan satu kali proses pengolahan menjadi dua kali dalam satu hari. Satu kali pengolahan memerlukan waktu 13 jam, 12 jam untuk proses memasak dan sisa waktu digunakan untuk mengangkat Ayam Be Keren yang sudah matang. Begitu berlanjut seterusnya. Kendala masih tetap 
dirasakan walaupun sudah meningkatkan kapasitas produksi menjadi dua kali sehari, dikarenakan pesanan sudah datang dari berbagai ragam konsumen yang membutuhkan, seperti pesanan catering, pesanan untuk kebutuhan upacara agama, pesanan untuk pengiriman luar daerah, bahkan pernah Ibu Agung melayani pesanan rutin ke Ibukota Jakarta untuk waktu yang cukup lama, setiap pagi Ibu Agung harus menyiapkan 50 bungkus Ayam Be Keren diantar ke airport untuk dikirim ke Jakarta. Selain itu pesanan perseorangan dan dari masyarakat lokal juga terus ada setiap harinya.

c. Jumlah Tenaga Kerja

Faktor yang paling dirasakan cukup berpengaruh dengan meningkatnya jumlah pesanan adalah tenaga kerja. Ibu Agung mengalami kendala tenaga kerja dalam hal proses pengolahannya. Untuk diketahui bahwa di Kabupaten Bangli, penduduk remajanya hampir sebagian besar bekerja merantau ke luar daerah bahkan luar negeri. Penduduk remaja Bangli beramai-ramai bekerja di kapal pesiar dan daratan di sektor pariwisata. Sedangkan untuk ibu-ibu atau orang tua, terkendala dengan waktu, setelah selesai pekerjaan di rumah baru bisa bekerja di pengolahan Ayam $B e$ Keren Adapun pekerjaan utama yang dimaksud adalah pekerjaan rumah tangga, seperti memasak, bersih-bersih sampai dengan sembahyang, menyama braya (kegiatan sosial), dan berbagai kegiatan lainnya yang umumnya begitu sering dilakukan (kegiatan ritual persembahyangan). Jadi bekerja mencari nafkah itu bukanlah yang utama bagi masyarakat setempat. Di Kabupaten Bangli pekerjaan umum yang dilakukan masyarakatnya adalah bertani dan berkebun.

d. Waktu Pengolahan

Kendala lain yang dirasakan oleh Ibu Agung yaitu waktu atau lama pengolahan memasak $B e$ Keren. Ibu Agung sampai dengan saat 
ini terkendala di waktu pengolahan. Tahap I pengolahan yaitu biasa mulai dikerjakan dini hari mulai pukul 04.00-16.00 dan bila sudah merencanakan akan menambah produksi maka akan berlanjut ke tahap II yang dimulai langsung di pk 16.00-04.00 keesokan harinya. Waktu pengolahan yang berlangsung penuh 24 jam, menjadi kendala tersendiri dikarenakan pada saat berlangsungnya proses memasak harus diawasi dan dilakukan pengecekan secara berkala terhadap masakan $B e$ Keren, karena sewaktu-waktu sekam dan sabut kelapa perlu ditambahkan, untuk memastikan agar tingkat kehangatan disekeliling Ayam Be Keren dapat terjaga sehingga memberi hasil kematangan yang baik. Karena adanya kendala waktu dan kendala tenaga kerja, Ibu Agung menghentikan proses dua kali produksinya menjadi satu kali saja dalam sehari. Sehingga rata-rata kapasitas maksimum dapur tidak dapat terpenuhi atau hanya dapat menghsilkan $50 \%$ dari total kapasitas yang ada.

e. Adat-istiadat dan Kegiatan Ritual Keagamaan

Dengan adanya kendala di atas, faktor lain yang tidak kalah peranannya menjadi kendala tersendiri bagi Ibu Agung yaitu kegiatan adat/ menyama braya di lingkungan Br. Kawan, Bangli. Kegiatan adat tersebut seringkali menjadi faktor keterbatasan Ibu Agung dalam menerima pesanan dengan jumlah yang banyak dan rutin, dikarenakan kegiatan adat yang mengharuskan Ibu Agung sekeluarga untuk turut serta didalamnya. Seringkali kegiatan tersebut berlangsung mendadak, seperti upacara kematian dan pernikahan.

\subsection{Upaya Pengembangan Ayam Be Keren}

Hasil wawancara mengenai upaya pengembangan Ayam $B e$ Keren menurut Ibu Anak Agung Sugantini: 
"Pengolahan makanan tradisional $\mathrm{Be}$ Keren ini memang sudah lama tidak ditemukan lagi, dapat dikatakan hanya tertinggal satu-satunya, dan berkembang apa adanya. Perkembangan makanan yang ada sampai sekarang ini sepenuhnya dilakukan oleh Saya dan Keluarga selaku pewaris dan penjual. Yang pernah kami lakukan sebatas mengikuti pameran makanan dan kegiatan perlombaan baik yang kami lakukan karena keinginan sendiri ataupun ajakan/ informasi dari pemerintah setempat. Upaya lain yang pernah kami lakukan juga menyediakan tempat kami untuk dikunjungi dan diliput baik oleh wisatawan maupun pelancong yang ingin mengetahui bagaimana proses pengolahan $\mathrm{Be}$ Keren, atau hanya sekedar ingin melihat area dapur tempat pengolahannya saja, bahkan juga ada yang hanya ingin tahu mencoba membeli Ayam Keren ini untuk dinikmati. Selain itu kami juga berusaha merangkul masyarakat desa ini untuk melestarikan Ayam Keren yang merupakan warisan leluhur dengan melibatkan mereka dalam pengolahan bilamana ada kapasitas order yang melebihi, bahkan ikut menjualkannya, dan juga menjadi konsumennya langsung agar Ayam Keren dapat terus terjaga kelangsungannya. Saat ini masyarakat lokal tetap menjadi konsumen setia Be Keren, khususnya menjelang hari raya keagamaan dimana mereka menggunakan Ayam Be Keren untuk melengkapi aturan persembahyangan yang lakukan. Setelah upacara persembahyangan, Ayam Keren ini akan disantap bersama dengan keluarga" (Sugantini, 20 Januari 2019).

Upaya yang dilakukan dalam mengatasi kendala yang ada antara lain:

a. Tenaga kerja dirasakan sebagai kendala utama dalam pengembangan produksi $B e$ Keren. Untuk memenuhi pesanan yang ada, Ibu Agung mengajak/merekrut tiga orang karyawan remaja, dimana ketiga karyawannya tersebut berasal dari luar Kabupaten Bangli. Hal tersebut dilakukan oleh Ibu Agung mengingat kebutuhan yang ada yang mengharuskannya untuk merekrut pekerja tetap. Ketiga karyawan 
tersebut diajak tinggal bersama sehingga memudahkan koordinasi kerja.

b. Dengan adanya tenaga kerja yang bekerja penuh waktu, maka Ibu Agung dapat menghitung sekaligus menetapkan kapasitas produksi $\mathrm{Be}$ Keren dengan lebih baik dan teratur. Bilamana ada karyawan libur, maka Ibu Agung sudah dapat mengatur penerimaan pesanan dengan lebih baik.

c. Untuk pengembangan sarana dan prasarana, saat ini Ibu Agung masih dalam tahap perencanaan pengembangan untuk menambah area dapur dan area tempat makan untuk konsumen yang ingin menyantap langsung di tempat hidangan Ayam $B e$ Keren. Perencanaan penambahan dapur dan pendukung lainnya baru akan dilaksanakan bilamana Ibu Agung mempunyai tenaga kerja yang siap untuk menggantikannya sewaktu-waktu, yang dapat menjalankan dan melanjutkan usaha yang sudah turun-temurun diwariskan.

d. Waktu Pengolahan juga menjadi tidak begitu terkendala, dikarenakan Ibu Agung sudah dapat melakukan pembagian kerja. Dengan adanya tenaga kerja penuh waktu, proses produksi $B e$ Keren dapat dilakukan sesuai dengan kapasitas maksimal.

e. Ibu Agung tetap dapat melaksanakan kegiatan adat dengan baik, didukung oleh tenaga kerja yang telah dimiliki. Hanya saja Ibu Agung tetap terlibat dan bertanggung jawab penuh dalam hal penyiapan kebutuhan bahan pokok produksi, untuk kelancaran kegiatan pengolahan Ayam Be Keren.

\section{Penutup}

Potensi gastronomi makanan tradisional Bangli yang turuntemurun dan diwarisi oleh Ibu Agung, dapat dikatakan memenuhi kriteria keunikan, orijinalitas, otentisitas, dan keragaman yaitu khususnya dalam 
hal pengolahan/cara memasak, serta penampilan/presentasi yang menarik bagi konsumen/wisatawan sehingga berpotensi dan layak ditawarkan sebagai daya tarik wisata. Upaya-upaya yang dilakukan oleh Ibu Agung selaku pedagang dalam pengembangan makanan tradisional Bangli, yaitu dengan mengikuti kegiatan pameran kuliner bersama dan beberapa kegiatan lomba yang diselenggarakan oleh pemerintah, dapat dikatakan berperan penting dalam menjaga budaya dan tradisi warisan leluhur. Bentuk keterlibatan masyarakat Desa Adat Bangli dalam pengembangan makanan tradisional Bali yang dijual oleh Ibu Agung, yaitu keterlibatan sebagai konsumen yang punya andil turut serta dalam menjaga dan mengembangkan makanan tradisional Bangli "Be Keren". Dengan adanya konsumen, maka kelangsungan usaha yang dijalankan oleh Ibu Agung akan tetap dapat berjalan.

Berdasarkan simpulan yang ada, maka dapat diajukan rekomendasi untuk dilakukan oleh Ibu Agung antara lain, dengan menambah/ memperluas sarana dan prasarana sekaligus melakukan penataan yang lebih baik, baik untuk sarana memasak (dapur) dan sarana tempat berjualan yang lebih layak bagi konsumen, menambah kapasitas produksi untuk memenuhi permintaan konsumen, bahkan untuk memperluas pemasaran, serta menambah jumlah tenaga kerja agar bisa mendukung peningkatan kapasitas produksi dan memperluas jangkauan pemasaran. Dapat dilakukan dengan cara merangkul masyarakat setempat, utamanya ibu-ibu atau remaja yang tidak memiliki pekerjaan untuk turut serta dalam upaya pengembangan makanan tradisional khas Bangli "Be Keren".

Masyarakat Desa Adat Bangli diharapkan ikut berpartisipasi melestarikan dan mengembangkan makanan tradisional khas Bangli "Be Keren" yang merupakan warisan budaya dan tradisi turun-temurun sehingga menjadi keunikan tersendiri sebagai daya tarik wisata. Jadi 
masyarakat diharapkan tidak hanya sebatas sebagai konsumen tapi ikut menjadi pelaku usaha "pedagang" Be Keren. Melihat adanya peluang yang begitu besar, pemerintah diharapkan berperan serta untuk lebih intensif menghimbau masyarakat dan semua pihak terkait dalam pengembangan makanan tradisional khas Bangli, melalui pembuatan kebijakan-kebijakan untuk dapat lebih memperkenalkan produk lokal khas Bangli kepada wisatawan sekaligus untuk mengangkat potensi lokal yang ada seperti penggunaan bahan baku hasil pertanian lokal yang dapat dimanfaatkan lebih optimal sebagai wujud pengembangan kepariwisataan berkelanjutan.

\section{Daftar Pustaka}

Anonim, 2009, Undang-undang Republik Indonesia No. 10 Tahun 2009 tentang Kepariwisataan.

Assauri, Sofjan. 2001. Manajemen Produksi dan Operasi. Edisi Revisi Fakultas Universitas Indonesia. Jakarta.

Bucharin Alma, H. 2000. Manajemen Pemasaaran dan Pemasaran Jasa. Edisi Keempat. Alfabeta Bandung.

Cooper, C. And Jackson. S. L. 1995. DestinationLife Cycle: The Isle of The Man Case Study. (ed. Lesly, France) dalam The Earthscan Reader in Sustainable Tourism. UK: Earthscan Publication Limited. Ernayanti, dkk. 2003. Ensiklopedi Makanan Tradisional di Pulau Jawa dan Pulau Madura. Deputi bidang pelestarian dan pengembangan kebudayaan, asdep. Urusan Kepercayaan Terhadap Tuhan YangMaha Esa. Jakarta: Proyek pelestarian dan pengembangan tradisi dan kepercayaan.

Kotler, P., Bowen, J., Makens, J. 2002. PemasaranPerhotelan dan Kepariwisataan. Jilid II Edisi Bahasa Indonesia. Jakarta: Pearson Education Asia Ptc. Ltd. dan PT. Prenhallindo.

Nazir, Moh. 2003. Metode Penelitian. Jakarta: Penerbit Ghalia Indonesia.

Pendit, I Nyoman S. 2006. Ilmu Pariwisata Sebuah Pengantar Perdana. Edisi Terbaru: dengan perbaikan-perbaikan, Jakarta: PT. Pradnya Paramita.

Sugiyono. 2010. Metode Penelitian Kuantitatf, Kualitatif dan $R \& D$. Bandung: Alfabeta.

Wikipedia. 2012. Gastronomi, http://id.wikipedia.org/wiki/Gastronomi. 10-55. 10/12/2012. 


\section{Profil Penulis}

I Gusti Ayu Ari Agustini, SST.Par., M.M. lahir di Denpasar, 09 Agustus 1980. Menamatkan Sarjana Program Studi Pariwisata di Universitas Udayana pada tahun 2006. Melanjutkan Pendidikan Pasca Sarjana Program Studi Manajemen dengan konsentrasi Manajemen Sumber Daya Manusia di Pasca Sarjana Universitas Udayana yang diselesaikan tahun 2011. Memiliki pengalaman kerja di bidang operasional manajemen selama 12 tahun, dan juga sebagai seorang Entrepreneurship di bidang kuliner semenjak empat tahun lalu. Pengalaman ini membawanya menjadi Dosen D-III Seni Kuliner di Politeknik Internasional Bali. 
I Gusti Ayu Ari Agustini

100 JOURNEY Volume 2 Nomor 1, Desember 2019 